\title{
Misexpression of CCAAT/enhancer binding protein beta causes osteopenia
}

\author{
Stefano Zanotti ${ }^{1}$, Lisa Stadmeyer ${ }^{1}$, Anna Smerdel-Ramoya ${ }^{1}$, Deena Durant ${ }^{1}$ and Ernesto Canalis ${ }^{1,2}$ \\ ${ }^{1}$ Department of Research, Saint Francis Hospital and Medical Center, 114 Woodland Street, Hartford, Connecticut 06105-1299, USA \\ ${ }^{2}$ The University of Connecticut School of Medicine, Farmington, Connecticut 06030, USA \\ (Correspondence should be addressed to E Canalis; Email: ecanalis@stfranciscare.org)
}

\begin{abstract}
CCAAT/enhancer binding proteins (C/EBPs) are expressed by osteoblasts and adipocytes during differentiation. C/EBP $\beta$ is critical for adipogenesis; however, its role in osteoblastogenesis is unclear, and its function in the postnatal skeleton is not known. To study $\mathrm{C} / \mathrm{EBP} \beta$ in osteoblasts in vivo, we created transgenic mice expressing full length $\mathrm{C} / \mathrm{EBP} \beta$ under the control of a $3.8 \mathrm{~kb}$ fragment of the human osteocalcin promoter. Two transgenic lines were established in a friend leukemia virus strain $\mathrm{B}$ genetic background, and compared with wild type littermate controls. Both C/EBP $\beta$ transgenic lines exhibited osteopenia, with a $30 \%$ decrease in bone volume, due to a decrease in trabecular number. The number of osteoblasts and osteoclasts per bone perimeter was not changed. Bone marrow stromal cells from C/EBP $\beta$ transgenics showed reduced mineralization, and reduced alkaline phosphatase mRNA levels. Calvarial osteoblasts from
\end{abstract}

$\mathrm{C} / \mathrm{EBP} \beta$ transgenics displayed reduced alkaline phosphatase activity. To determine the consequences of the Cebpb deletion in vivo, the phenotype of Cebpb null mice was compared with that of wild type controls of identical genetic composition. Cebpb null mice exhibited reduced weight, body fat, and bone mineral density, and decreased bone volume, due to a decrease in trabecular number. The number of osteoblasts and osteoclasts per bone perimeter was not changed. C/EBP $\beta$ downregulation by RNA interference in calvarial osteoblasts had no effect on osteoblast differentiation/function. The phenotype of the Cebpb inactivation may be secondary to systemic indirect effects, and to direct effects of C/EBP $\beta$ in osteoblasts. In conclusion, C/EBP $\beta$ plays a role in mesenchymal cell differentiation and its misexpression in vivo causes osteopenia.

Journal of Endocrinology (2009) 201, 263-274

\section{Introduction}

CCAAT/enhancer binding proteins (C/EBPs) are a family of transcription factors that play a role in cell proliferation, differentiation, and apoptosis (Nerlov 2007). Six members of the C/EBP family have been characterized and are termed $\alpha$, $\beta, \delta, \gamma, \varepsilon$, and $\zeta$, which is also known as $\mathrm{C} / \mathrm{EBP}$ homologous protein (CHOP) (Ramji \& Foka 2002). C/EBP proteins contain a highly conserved leucine-zipper DNA-binding domain (DBD) and a leucine dimerization domain that enables the formation of homo- and hetero-dimers, which bind to similar DNA sequence motifs. C/EBPs act as regulators of gene expression either by direct DNA binding or by interacting with other transcription factors, including peroxisome proliferator-activated receptor- $\gamma 2$, retinoic acid receptor $\alpha$, runt-related transcription factor-2 (Runx-2), and nuclear factor of activated T-cells (Clarke et al. 1997, Gutierrez et al. 2002, Yang \& Chow 2003, Nerlov 2007). $\mathrm{C} / \mathrm{EBPs}$ are expressed in multiple cell types, including osteoblasts and adipocytes, and C/EBP $\beta$ and $\delta$ are required for adipogenesis (Rosen et al. 2000, Pereira et al. 2002, Hata et al. 2005, Wiper-Bergeron et al. 2007).
$\mathrm{C} / \mathrm{EBP} \beta$ exists in three different isoforms, which are translated from different initiation sites within the same mRNA. All three isoforms share the same DNA-binding domain; however, differences in the length of the amino terminal end, determine different functions (Calkhoven et al. 2000). The full length isoform, termed as liver-enriched activating protein ${ }^{\star}$ or LAP $\star$, consists of 296 amino acids and acts as a transcriptional activator, it is commonly referred to as C/EBP $\beta$. A second isoform, termed LAP, lacks the first 21 amino acids present in the amino terminal end of full length $\mathrm{LAP}^{\star}$, and it is generated from a different translation start site. LAP and LAP ${ }^{\star}$ are functionally identical. A third isoform, termed as liver-enriched inhibitory protein (LIP), consists of 144 amino acids and acts as a dominant negative inhibitor of both LAP^ and LAP, since it lacks transactivating activity but retains the ability to bind DNA and to dimerize with the other C/EBP $\beta$ isoforms (Fig. 1; Nerlov 2007). The function of $\mathrm{C} / \mathrm{EBP} \beta$ is regulated by acetylation and phosphorylation at specific residues (Tang et al. 2005, Cesena et al. 2007, Li et al. 2007). Acetylation at Lys-39 of murine $\mathrm{C} / \mathrm{EBP} \beta$ is necessary to activate the transcription of $C-f o s$ and Cebpa, whereas sequential phosphorylation is required for the acquisition of 


\section{A} LAP*

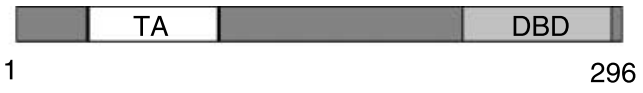

LAP

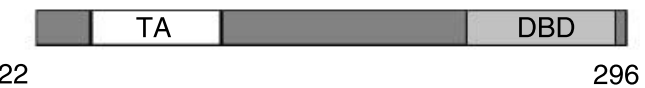

transgenic mice overexpressing $\mathrm{C} / \mathrm{EBP} \beta$ under the control of a $3.8 \mathrm{~kb}(\mathrm{~kb})$ fragment of the osteoblast specific human osteocalcin promoter, and determined their body composition and skeletal phenotype. Cebpb null mice were also studied, and their body composition and skeletal phenotype determined.

\section{Materials and methods}

\section{Generation of transgenic mice and cebpb null mice}

After introduction of an optimal Kozak consensus sequence upstream of the translation initiation codon, an $890 \mathrm{bp}$ (bp) fragment, coding for full length murine $\mathrm{C} / \mathrm{EBP} \beta$ or LAP $\star$ (S L McKnight, Department of Biochemistry, University of Texas Southwestern Medical Center, Dallas, TX, USA), was cloned downstream of a $182 \mathrm{bp}$ artificial intron and a $3.8 \mathrm{~kb}$ fragment of the human osteocalcin promoter (E Gardiner, University of Queensland, Brisbane, Australia), and upstream of polyadenylation sequences and a $3.5 \mathrm{~kb}$ fragment of the $3^{\prime}$ untranslated region and flanking DNA of the Osteocalcin gene (Fig. 1; Cao et al. 1991, Sims et al. 1997). Nucleotide sequence analysis confirmed the absence of mutations and correct orientation of the construct. Microinjection of linearized DNA into pronuclei of fertilized oocytes from FVB (for tropism to friend leukemia virus strain B (FVB)) inbred mice, and transfer of microinjected fertilized eggs into pseudopregnant FVB mice were carried out at the transgenic facility of the University of Connecticut Health Center (Farmington, CT, USA). Positive founders were identified by Southern blot analysis of tail DNA (Irwin 1989). Founder mice were bred to wild type FVB mice to generate transgenic lines, and their phenotype was examined.

To study the effects of the Cebpb deletion in vivo, Cebpb null heterozygous mice $\left(C_{e b p} b^{+/-}\right.$) (S Akira, Osaka University, Osaka, Japan) were re-derived in a C57BL/6 background, and backcrossed five times to obtain a uniform genetic background (Tanaka et al. 1995). Cebpb null homozygous mice $\left(C e b p b^{-/-}\right)$were obtained by intermating $C e b p b^{+/-}$ mice, and their phenotype was examined. All animal experiments were approved by the Animal Care and Use Committee of Saint Francis Hospital and Medical Center.

$X$-ray analysis, bone mineral density, and body composition

Radiography was either performed in C/EBP $\beta$ transgenic and wild type littermate controls or in $C e b p b^{-/-}$mice and, age and sex, matched wild type controls of the same genetic composition. The mice were anesthetized with tribromoethanol (Sigma-Aldrich), and the X-rays were performed at an intensity of $30 \mathrm{kw}$ for $20 \mathrm{~s}$ on a Faxitron X-ray system (model MX 20, Faxitron X-Ray Corp., Wheeling, IL, USA). Total bone mineral density (BMD) $\left(\mathrm{g} / \mathrm{cm}^{2}\right)$ and total body fat $(\mathrm{g})$ were measured on anesthetized mice using the PIXImus small animal DEXA system (GE Medical System/LUNAR, 
Madison, WI, USA; Nagy et al. 2001). Calibrations were performed with a phantom of defined value, and quality assurance measurements were performed before each use. The coefficient of variation for total BMD is less than $1 \%(n=9)$.

\section{Bone histomorphometric analysis}

Static and dynamic histomorphometry was carried out on transgenic mice and wild type littermate controls and Cebpb $b^{-/-}$mice and wild type, sex and age, matched controls of the same genetic composition. Mice were injected with calcein, $20 \mathrm{mg} / \mathrm{kg}$, and demeclocycline, $50 \mathrm{mg} / \mathrm{kg}$, at an interval of 2 days for 1 and 1.5 month old animals and 7 days for 3-month old animals. The mice were killed by $\mathrm{CO}_{2}$ inhalation 2 days after the demeclocycline injection. Longitudinal sections, $5 \mu \mathrm{m}$ thick, were cut on a microtome (Microm, Richards-Allan Scientific, Kalamazoo, MI, USA) and stained with $0 \cdot 1 \%$ toluidine blue or von Kossa. Static parameters of bone formation and resorption were measured in a defined area between 181 and $1080 \mu \mathrm{m}$ from the growth plate, using an OsteoMeasure morphometry system (Osteometrics, Atlanta, GA, USA; Gazzerro et al. 2005). Osteoclasts were identified as multinucleated cells on the trabecular surface and their identity confirmed by the expression of tartrate resistant acid phosphatase determined by histochemical analysis of selected cells, using a commercial kit according to manufacturer's instructions (Sigma-Aldrich). For dynamic histomorphometry, mineralizing surface per bone surface and mineral apposition rate were measured on unstained sections under u.v. light, using a B-2A set long pass filter, and bone formation rate (BFR) was calculated. The terminology and units used are those recommended by the Histomorphometry Nomenclature Committee of the American Society for Bone and Mineral Research (Parfitt et al. 1987).

\section{Serum C-terminal cross-linked telopeptide of type I collagen}

The bone remodeling marker cross-linked telopeptide of type I collagen (CTX) was measured in serum by ELISA using RatLaps ELISA kits (Nordic Bioscience Diagnostics, Herlev, Denmark), according to manufacturer's instructions.

\section{Cell cultures}

1-month old $\mathrm{C} / \mathrm{EBP} \beta$ heterozygous transgenic and wild type littermate controls from both sexes were killed by $\mathrm{CO}_{2}$ asphyxiation, the femurs were aseptically removed and used to recover bone marrow stromal cells by centrifugation as described (Gazzerro et al. 2005). Cells were plated at a density of $5 \times 10^{5}$ cells $/ \mathrm{cm}^{2}$ and cultured in minimum essential medium ( $\alpha$-MEM, Invitrogen) containing 15\% fetal bovine serum (FBS, Atlanta Biologicals, Norcross, GA, USA) at $37{ }^{\circ} \mathrm{C}$ in a humidified $5 \% \mathrm{CO}_{2}$ incubator. Confluent cells were switched to $\alpha$-MEM containing $10 \%$ FBS in the presence of $100 \mu \mathrm{g} / \mathrm{ml}$ ascorbic acid and $5 \mathrm{mM} \beta$-glycerophosphate and cultured up to 2 weeks to assess changes in mineralized nodule formation and gene expression.

Osteoblasts were isolated from parietal bones of 3- to 5-day old $\mathrm{C} / \mathrm{EBP} \beta$ heterozygous transgenic and wild type control littermates from both sexes, by sequential collagenase digestions, as previously described (McCarthy et al. 1990). Cells were cultured in DMEM (Invitrogen) supplemented with non-essential amino acids, $20 \mathrm{mM}$ HEPES, $100 \mu \mathrm{g} / \mathrm{ml}$ ascorbic acid, and 10\% FBS. Osteoblasts were cultured to $70 \%$ confluence and trypsinized; these first passage cells were used for subsequent experiments. Cells were cultured for up to 10 days after confluence, in the presence of $100 \mu \mathrm{g} / \mathrm{ml}$ ascorbic acid and $5 \mathrm{mM} \beta$-glycerophosphate (Sigma-Aldrich) to assess changes in gene expression, and treated with bone morphogenetic protein-2 (BMP-2, Wyeth Research, Collegeville, PA, USA) or control vehicle to determine alkaline phosphatase activity (APA).

\section{$R N A$ interference}

To downregulate $\mathrm{C} / \mathrm{EBP} \beta$ expression in vitro, a 19-mer double stranded small interfering (si) RNA targeted to the murine $\mathrm{C} / \mathrm{EBP} \beta$ mRNA sequence was obtained commercially, and a scrambled 19-mer small interfering RNA (siRNA) with no homology to known mouse or rat sequences was used as a control (Applied Biosystems, Foster City, CA, USA; Elbashir et al. 2001, Sharp 2001). C/EBP $\beta$ or scrambled siRNA, both at $20 \mathrm{nM}$, were transfected into sub-confluent primary murine osteoblasts using siLentFect lipid reagent, in accordance with manufacturer's instructions (BioRad). Cells were allowed to recover for $24 \mathrm{~h}$ prior to the determination of APA. To ensure adequate $\mathrm{C} / \mathrm{EBP} \beta$ downregulation, and to measure mRNA levels of osteoblast markers, total RNA was extracted in parallel cell cultures $96 \mathrm{~h}$ after the transfection of siRNAs, and mRNA levels determined by real-time reverse transcription-PCR (RT-PCR).

\section{Cytochemical assays and $A P A$}

To determine mineralized nodule formation, bone marrow stromal cells were fixed with $3 \cdot 7 \%$ formaldehyde and stained with 2\% Alizarin Red (Sigma-Aldrich; DAHL 1952). APA was determined in $0.5 \%$ Triton X-100 cell extractsby the hydrolysis of $p$-nitrophenyl phosphate to $p$-nitrophenolmeasured by spectroscopy at $405 \mathrm{~nm}$ after $10 \mathrm{~min}$ of incubation at room temperature according to the manufacturer's instructions (Sigma-Aldrich). Data are expressed as picomoles of $p$-nitrophenol released per min per $\mathrm{mg}$ of protein. The total protein content was determined in cell extracts by the DC protein assay, in accordance with manufacturer's instructions (Bio-Rad). 
Table 1 Weight and body composition of 1 and 3 month old C/EBP $\beta$ transgenics and wild-type littermate control mice

\section{\begin{tabular}{lll} 
Weight Total BMD Total body fat \\
\hline
\end{tabular}}

1-month old heterozygous

Female

$\begin{array}{llll}\text { Wild type } & 12 \cdot 6 \pm 0 \cdot 4 & 336 \pm 8 & 1 \cdot 8 \pm 0 \cdot 1 \\ \text { C/EBP } \beta \text { transgenics } & 12 \cdot 3 \pm 0 \cdot 2 & 343 \pm 5 & 2 \cdot 2 \pm 0 \cdot 1 \\ \text { Male } & & & \\ \text { Wild type } & 19 \cdot 5 \pm 0 \cdot 6 & 365 \pm 5 & 2 \cdot 8 \pm 0 \cdot 1 \\ \text { C/EBP } \beta \text { transgenics } & 18 \cdot 7 \pm 0 \cdot 9 & 354 \pm 7 & 2 \cdot 2 \pm 0 \cdot 4\end{array}$

1-month old homozygous

Female

$\begin{array}{llll}\text { Wild type } & 16 \cdot 6 \pm 0 \cdot 5 & 342 \pm 10 & 3 \cdot 0 \pm 0 \cdot 1\end{array}$

C/EBP $\beta$ transgenics $\quad 15 \cdot 3 \pm 0 \cdot 7 \quad 324 \pm 4 \quad 2 \cdot 9 \pm 0 \cdot 1$

3-month old heterozygous

Female

$\begin{array}{llll}\text { Wild type } & 21 \cdot 7 \pm 0 \cdot 8 & 502 \pm 9 & 3 \cdot 8 \pm 0 \cdot 1 \\ \text { C/EBP } \beta \text { transgenics } & 21 \cdot 6 \pm 1 \cdot 2 & 479 \pm 7 & 3 \cdot 8 \pm 0 \cdot 1 \\ \text { Male } & & & \\ \text { Wild type } & 26 \cdot 8 \pm 0 \cdot 4 & 470 \pm 4 & 5 \cdot 0 \pm 0 \cdot 1 \\ \text { C/EBP } \beta \text { transgenics } & 26 \cdot 3 \pm 0 \cdot 7 & 463 \pm 3 & 4 \cdot 6 \pm 0 \cdot 3\end{array}$

Weight $(\mathrm{g})$, total BMD $\left(\mathrm{g} / \mathrm{cm}^{2} \times 10^{4}\right)$, and total body fat $(\mathrm{g})$ were obtained from 1- or 3-month old C/EBP $\beta$ transgenics and wild type littermate controls using a PIXImus small animal DEXA system. BMD was calculated by dividing the bone mineral content $(\mathrm{g}) /$ bone area $\left(\mathrm{cm}^{2}\right)$, and total fat $(\mathrm{g})$ was measured directly by the instrument. Values are means \pm s.E.M. $(n=5-12)$.

\section{Real time RT-PCR}

Total RNA was extracted from cell cultures and mRNA levels determined by real-time RT-PCR (Nazarenko et al. 2002a, b). For this purpose, $5 \mu \mathrm{g}$ RNA were reverse-transcribed using SuperScript III Platinum Two-Step qRT-PCR kit (Invitrogen), according to the manufacturer's instructions, and amplified in the presence of CGGTTAGGGCGTCTCCACAGTAAC[FAM]G-3' and 5'-CTTGGAGAGGGCCACAAAGG-3' ${ }^{\prime}$ primers for alkaline phosphatase; 5'-CGGATTGAACCGAGACAACTACATA[FAM]G-3“ and 5'CGCCACCTACAATCAGGCTCT-3' primers for C/EBP $\beta ; 5^{\circ}$-CGAAGTTACATGACACTGGGCTT[FAM]G-3' and $5^{\prime}$-CCCAGCACAACTCCTCCCTA-3' primers for osteocalcin; 5'-CGAACCGGATAATGTGAAGTTCAAGGTT[FAM]G-3' and 5'-CTGCTTCAGCTTCTCTGCCTTT-3' primers for ribosomal protein L38 (RPL38), and Platinum Quantitative PCR SuperMix-UDG (Invitrogen) at $60{ }^{\circ} \mathrm{C}$ for 45 cycles. Transcript copy number was estimated by comparison with a standard curve constructed using C/EBP $\beta$ (S.L. McKnight), osteocalcin (J.B. Lian, University of Massachusetts, Worcester, MA USA; Lian et al. 1989), and alkaline phosphatase (American Type Culture Collection; ATCC, Manassas, VA, USA) cDNAs, corrected for RPL38 copy number (ATCC; Kouadjo et al. 2007). Reactions were conducted in a 96-well spectrofluorometric thermal iCycler (Bio-Rad), and fluorescence was monitored during every PCR cycle at the annealing step.

\section{Statistical analysis}

Data are expressed as means \pm s.E.M. Statistical differences were determined by Student's $t$-test or ANOVA.

\section{Results}

\section{$C / E B P \beta$ transgenic mice}

Two lines of FVB mice overexpressing C/EBP $\beta$ under the control of the $3.8 \mathrm{~kb}$ human osteocalcin promoter were established. The transgenic lines expressed 8 and 16 copies of the transgene. Both lines had a similar phenotype and the line

Table 2 Femoral static histomorphometry of 1-month old female $\mathrm{C} / \mathrm{EBP} \beta$ transgenic mice and wild type littermate controls

\begin{tabular}{|c|c|c|}
\hline & Wild type & $\begin{array}{l}\mathrm{C} / \mathrm{EBP} \beta \\
\text { transgenics }\end{array}$ \\
\hline \multicolumn{3}{|l|}{ Heterozygous } \\
\hline 3one volume/tissue volume (\%) & $11 \cdot 0 \pm 1 \cdot 3$ & $6 \cdot 4 \pm 0 \cdot 8^{*}$ \\
\hline abecular separation $(\mu \mathrm{m})$ & $90 \cdot 4 \pm 6 \cdot 0$ & $120 \cdot 5 \pm 21 \cdot 4$ \\
\hline abecular number $\left(\mathrm{mm}^{-1}\right)$ & $9 \cdot 9 \pm 0 \cdot 5$ & $6 \cdot 2 \pm 0 \cdot 5^{*}$ \\
\hline abecular thickness $(\mu \mathrm{m})$ & $11 \cdot 1 \pm 0 \cdot 8$ & $10 \cdot 3 \pm 0 \cdot 6$ \\
\hline $\begin{array}{l}\text { Dsteoblast surface/bone } \\
\text { surface }(\%)\end{array}$ & $33 \cdot 9 \pm 3 \cdot 2$ & $31 \cdot 0 \pm 0 \cdot 9$ \\
\hline $\begin{array}{l}\text { Number of osteoblasts/bone } \\
\text { perimeter }\left(\mathrm{mm}^{-1}\right)\end{array}$ & $61 \cdot 6 \pm 5 \cdot 8$ & $60 \cdot 1 \pm 2 \cdot 2$ \\
\hline $\begin{array}{l}\text { Number of osteoblasts/tissue } \\
\text { area }\left(\mathrm{mm}^{-2}\right)\end{array}$ & $950 \cdot 8 \pm 44 \cdot 9$ & $579 \cdot 2 \pm 24 \cdot 3 *$ \\
\hline $\begin{array}{l}\text { Osteoclast surface/bone } \\
\text { surface }(\%)\end{array}$ & $14 \cdot 1 \pm 0 \cdot 4$ & $13 \cdot 7 \pm 0 \cdot 1$ \\
\hline $\begin{array}{l}\text { Number of osteoclasts/bone } \\
\text { perimeter }\left(\mathrm{mm}^{-1}\right)\end{array}$ & $12 \cdot 7 \pm 0 \cdot 3$ & $12 \cdot 6 \pm 0 \cdot 4$ \\
\hline $\begin{array}{l}\text { Number of osteoclasts/tissue } \\
\text { area }\left(\mathrm{mm}^{-2}\right)\end{array}$ & $198 \cdot 6 \pm 11 \cdot 3$ & $121 \cdot 3 \pm 6 \cdot 0^{*}$ \\
\hline roded surface/bone surface (\%) & $28 \cdot 0 \pm 1 \cdot 4$ & $27 \cdot 4 \pm 0 \cdot 2$ \\
\hline $\begin{array}{l}\text { Number of adipocytes/tissue } \\
\text { area }\left(\mathrm{mm}^{-2}\right)\end{array}$ & $65 \cdot 9 \pm 9 \cdot 0$ & $83 \cdot 7 \pm 19 \cdot 7$ \\
\hline \multicolumn{3}{|l|}{ Homozygous } \\
\hline 3one volume/tissue volume (\%) & $12 \cdot 1 \pm 0 \cdot 6$ & $7 \cdot 5 \pm 0 \cdot 9 *$ \\
\hline rabecular separation $(\mu \mathrm{m})$ & $87 \cdot 6 \pm 4 \cdot 7$ & $135 \cdot 7 \pm 14 \cdot 8^{*}$ \\
\hline rabecular number $\left(\mathrm{mm}^{-1}\right)$ & $10 \cdot 1 \pm 0 \cdot 5$ & $7 \cdot 0 \pm 0 \cdot 6^{*}$ \\
\hline rabecular thickness $(\mu \mathrm{m})$ & $11 \cdot 9 \pm 0 \cdot 2$ & $10 \cdot 7 \pm 0 \cdot 5$ \\
\hline $\begin{array}{l}\text { Osteoblast surface/bone } \\
\text { surface }(\%)\end{array}$ & $28 \cdot 0 \pm 2 \cdot 4$ & $29 \cdot 2 \pm 3 \cdot 3$ \\
\hline $\begin{array}{l}\text { Number of osteoblasts/bone } \\
\text { perimeter }\left(\mathrm{mm}^{-1}\right)\end{array}$ & $61 \cdot 0 \pm 7 \cdot 0$ & $65 \cdot 4 \pm 6 \cdot 9$ \\
\hline $\begin{array}{l}\text { Number of osteoblasts/tissue } \\
\text { area }\left(\mathrm{mm}^{-2}\right)\end{array}$ & $970 \cdot 9 \pm 124 \cdot 8$ & $718 \cdot 7 \pm 96 \cdot 5$ \\
\hline $\begin{array}{l}\text { Osteoclast surface/bone } \\
\text { surface }(\%)\end{array}$ & $13 \cdot 3 \pm 0 \cdot 8$ & $14 \cdot 5 \pm 0 \cdot 7$ \\
\hline $\begin{array}{l}\text { Number of osteoclasts/bone } \\
\text { perimeter }\left(\mathrm{mm}^{-1}\right)\end{array}$ & $13 \cdot 0 \pm 0 \cdot 4$ & $13 \cdot 9 \pm 0 \cdot 4$ \\
\hline $\begin{array}{l}\text { Number of osteoclasts/tissue } \\
\text { area }\left(\mathrm{mm}^{-2}\right)\end{array}$ & $207 \cdot 5 \pm 16 \cdot 0$ & $152 \cdot 3 \pm 12 \cdot 8^{*}$ \\
\hline roded surface/bone surface (\%) & $24 \cdot 4 \pm 0 \cdot 7$ & $25 \cdot 3 \pm 0 \cdot 6$ \\
\hline Number of adipocytes/tissue & $145 \cdot 4 \pm 16 \cdot 7$ & $150 \cdot 0 \pm 11 \cdot 8$ \\
\hline
\end{tabular}

Number of adipocytes/tissue area $\left(\mathrm{mm}^{-2}\right)$

Heterozygous

Bone volume/tissue volu

umber of osteoblasts/bone

area $\left(\mathrm{mm}^{-2}\right)$

surface $(\%)$

area $\left(\mathrm{mm}^{-2}\right)$

Eroded surface/bone surface $(\%)$

Number of adipocytes/tissue

Homozygous

Trabecular separation $(\mu \mathrm{m})$

Trabecular number $\left(\mathrm{mm}^{-1}\right)$

Trabecular thickness $(\mu \mathrm{m})$

perimeter $\left(\mathrm{mm}^{-1}\right)$

Number of osteoblasts/tissue

Osteoclast surface/bone

perimeter $\left(\mathrm{mm}^{-1}\right)$

Number of osteoclasts/tissue areat

Bone histomorphometry was performed on femurs from 1 month old female C/EBP $\beta$ transgenics and wild type littermate controls. Values are means \pm S.E.M.; $n=3-9$; *Significantly different from wild type controls, $P<0 \cdot 05$. 
expressing 16 copies of the transgene was characterized in detail. $\mathrm{C} / \mathrm{EBP} \beta$ transgenic mice were compared with wild type littermate controls of identical sex, at the age of 1 month, a time of high activity of the osteocalcin promoter, or at the age of 3 months (Frenkel et al. 1997). In the offspring of $\mathrm{C} / \mathrm{EBP} \beta$ heterozygous mice intermatings, the ratio of wild type, $\mathrm{C} / \mathrm{EBP} \beta$ heterozygous, and $\mathrm{C} / \mathrm{EBP} \beta$ homozygous was 29:60:11 for females and 32:63:5 for males. As a consequence, the number of $\mathrm{C} / \mathrm{EBP} \beta$ homozygous mice was limited, and this only allowed a detailed histomorphometric analysis of homozygous female mice. We suspect that the non-Mendelian distribution of the transgenic allele is due to intrauterine lethality, likely because of transgene expression in the central nervous system, where the osteocalcin promoter is also active (Frenkel et al. 1997). There was no significant difference in weight and total body fat in either 1- or 3-month old $\mathrm{C} / \mathrm{EBP} \beta$ transgenic mice, when compared with wild type littermate controls (Table 1). Contact radiography did not reveal any obvious skeletal abnormality, and there was no difference in BMD between transgenics and controls (Table 1).

Bone histomorphometric analysis of distal femurs from 1-month old female C/EBP $\beta$ transgenics revealed a decrease in bone volume/tissue volume, secondary to a reduction in the number of trabeculae (Table 2, Fig. 2A). A similar decrease in bone volume was observed in male heterozygous transgenics (Table 3, Fig. 2B). The number of osteoblasts per tissue area was decreased in $\mathrm{C} / \mathrm{EBP} \beta$ transgenics, possibly due to the decreased bone volume, since the number of osteoblasts per bone perimeter, and osteoblast surface/bone surface were not different from controls (Tables 2 and 3). Changes in bone volume were not associated with an increase in bone resorption since the number of osteoclasts per bone perimeter and eroded surface were not increased in transgenics when compared with controls (Tables 2 and 3). A modest decrease in the number of osteoclasts per tissue area was detected in female transgenics (Table 2). Serum concentrations of CTX (means \pm s.E.M.; $n=3-6$ ) were $26 \cdot 5 \pm 3 \cdot 1 \mathrm{ng} / \mathrm{ml}$ in female heterozygous $\mathrm{C} / \mathrm{EBP} \beta$ transgenic mice and $33 \cdot 3 \pm 1.9 \mathrm{ng} / \mathrm{ml}$ in wild type littermate controls; $30 \cdot 7 \pm 5.6 \mathrm{ng} / \mathrm{ml}$ in female homozygous transgenics and $32 \cdot 3 \pm 4 \cdot 0 \mathrm{ng} / \mathrm{ml}$ in wild type littermate controls; and $49.4 \pm 15.5 \mathrm{ng} / \mathrm{ml}$ in male heterozygous transgenics and $50 \cdot 4 \pm 7.4 \mathrm{ng} / \mathrm{ml}$ in wild-type littermate controls. The results indicate that $\mathrm{C} / \mathrm{EBP} \beta$ overexpression does not affect bone remodeling. There were no substantial differences between female and male phenotypes, and no change in mineral apposition rate (not shown) or BFR (Fig. 2) was detected in C/EBP $\beta$ transgenics. No significant change in the number of adipocytes per tissue area was observed in either female or male transgenics when compared with wild type littermate controls (Tables 2 and 3 ). This could be expected since $\mathrm{C} / \mathrm{EBP} \beta$ transcription was directed by the osteocalcin promoter, which is not active in adipocytic cells.
A Wild type
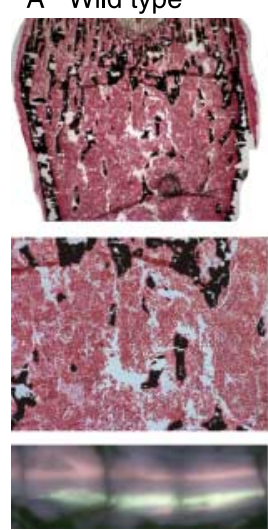

BV/TV

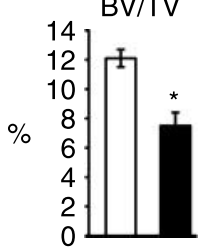

\section{C/EBP $\beta$ transgenic}
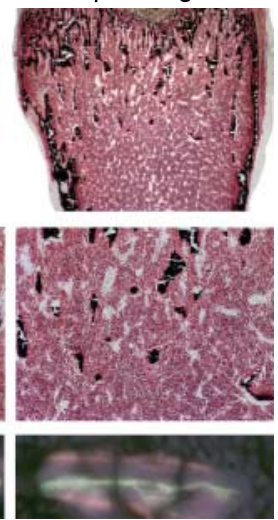

BFR/BS

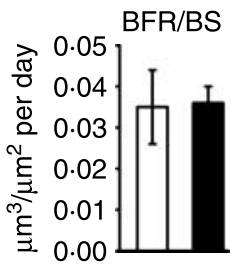

B Wild type
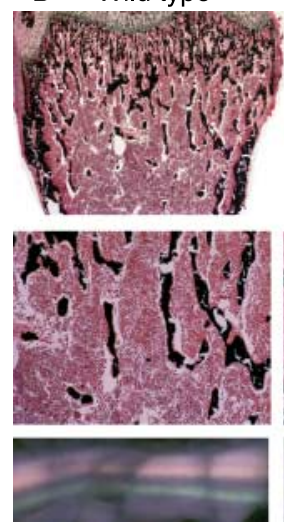

BV/TV

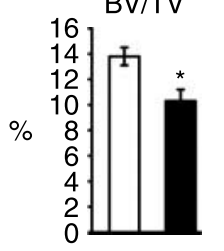

C/EBP $\beta$ transgenic
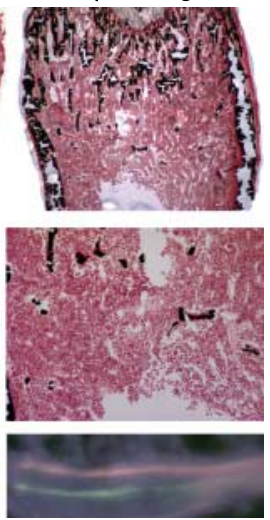

BFR/BS

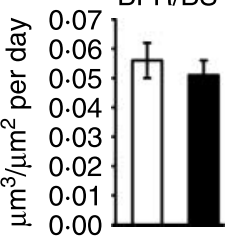

Figure 2 Representative histological sections and calcein/demeclocycline labels (upper panels) of femoral sections from 4 week old female homozygous (A) and male heterozygous (B) 1 month old C/EBP $\beta$ transgenic mice and wild type littermate controls stained with von Kossa without counter staining (final magnification $40 \times$ and $100 \times$ ) or unstained and examined under fluorescence microscopy (final magnification $100 \times$ ). In the lower panels, bars represent bone volume/tissue volume (BV/TV, \%), and BFR/bone surface (BFR/BS, $\mu \mathrm{m}^{3} / \mu^{2} /$ day) of C/EBP $\beta$ transgenics (black bars) and wild- type controls (white bars). Values are means \pm S.E.M., $n=3-9$. ${ }^{*}$ Significantly different from control mice, $P<0 \cdot 05$. 
Table 3 Femoral static histomorphometry of 1 -month old male $\mathrm{C} / \mathrm{EBP} \beta$ heterozygous transgenic mice and wild type littermate controls

\begin{tabular}{|c|c|c|}
\hline & Wild type & $\begin{array}{l}\mathrm{C} / \mathrm{EBP} \beta \\
\text { transgenics }\end{array}$ \\
\hline Bone volume/tissue volume (\%) & $13 \cdot 8 \pm 0 \cdot 7$ & $10 \cdot 3 \pm 0 \cdot 9 *$ \\
\hline Trabecular separation $(\mu \mathrm{m})$ & $79 \cdot 9 \pm 3 \cdot 5$ & $110 \cdot 3 \pm 9 \cdot 3 *$ \\
\hline Trabecular number $\left(\mathrm{mm}^{-1}\right)$ & $10 \cdot 9 \pm 0 \cdot 4$ & $8 \cdot 4 \pm 0 \cdot 6^{*}$ \\
\hline Trabecular thickness $(\mu \mathrm{m})$ & $12 \cdot 6 \pm 0 \cdot 3$ & $12 \cdot 1 \pm 0 \cdot 4$ \\
\hline $\begin{array}{l}\text { Osteoblast surface/bone } \\
\text { surface }(\%)\end{array}$ & $31 \cdot 0 \pm 1 \cdot 5$ & $29 \cdot 3 \pm 1 \cdot 3$ \\
\hline $\begin{array}{l}\text { Number of osteoblasts/bone } \\
\text { perimeter }\left(\mathrm{mm}^{-1}\right)\end{array}$ & $37 \cdot 4 \pm 1 \cdot 3$ & $33 \cdot 8 \pm 1 \cdot 5$ \\
\hline $\begin{array}{l}\text { Number of osteoblasts/tissue } \\
\text { area }\left(\mathrm{mm}^{-2}\right)\end{array}$ & $639 \cdot 8 \pm 24 \cdot 9$ & $449 \cdot 4 \pm 39 \cdot 3 *$ \\
\hline $\begin{array}{l}\text { Osteoclast surface/bone } \\
\text { surface }(\%)\end{array}$ & $6 \cdot 9 \pm 0 \cdot 4$ & $7 \cdot 9 \pm 0 \cdot 8$ \\
\hline $\begin{array}{l}\text { Number of osteoclasts/bone } \\
\text { perimeter }\left(\mathrm{mm}^{-1}\right)\end{array}$ & $5 \cdot 6 \pm 0 \cdot 3$ & $6 \cdot 6 \pm 0 \cdot 6$ \\
\hline $\begin{array}{l}\text { Number of osteoclasts/tissue } \\
\text { area }\left(\mathrm{mm}^{-2}\right)\end{array}$ & $95 \cdot 8 \pm 5 \cdot 2$ & $84 \cdot 7 \pm 5 \cdot 2$ \\
\hline Eroded surface/bone surface (\%) & $16 \cdot 8 \pm 0 \cdot 8$ & $17 \cdot 6 \pm 1 \cdot 1$ \\
\hline $\begin{array}{l}\text { Number of adipocytes/tissue } \\
\text { area }\left(\mathrm{mm}^{-2}\right)\end{array}$ & $269 \cdot 4 \pm 24 \cdot 1$ & $306 \cdot 9 \pm 40 \cdot 7$ \\
\hline
\end{tabular}

Bone histomorphometry was performed on femurs from 1-month old male $\mathrm{C} / \mathrm{EBP} \beta$ heterozygous transgenic mice and wild type littermate controls. Values are means \pm S.E.M.; $n=6-8 ; *$ Significantly different from wild type controls, $P<0 \cdot 05$.

Bone histomorphometric analysis of distal femurs from 3-month old female C/EBP $\beta$ heterozygous transgenics revealed a phenotype analogous to that observed at 1 month, and characterized by a decrease in bone volume/tissue volume, due to a reduction in the number of bone trabeculae (Table 4). BFR and mineral apposition rate were not affected (data not shown). Serum concentrations of CTX (means \pm s.E.M.; $n=4$ ) were $17 \cdot 8 \pm 1.9 \mathrm{ng} / \mathrm{ml}$ in female heterozygous $\mathrm{C} / \mathrm{EBP} \beta$ transgenic mice and $16 \cdot 3 \pm 1 \cdot 1 \mathrm{ng} / \mathrm{ml}$ in wild-type littermate controls, confirming that $\mathrm{C} / \mathrm{EBP} \beta$ overexpression does not affect bone remodeling.

Both transgenic lines studied displayed analogous skeletal phenotypes. In accordance with the line described, 1-month old male C/EBP $\beta$ heterozygous transgenics, from the line expressing eight copies of the transgene, exhibited a decrease in bone volume. Bone volume/tissue volume was (means \pm s.E.M.; $n=6-8$ ) $8 \cdot 0 \pm 0 \cdot 4 \%$ in controls and $5 \cdot 3 \pm 0.5 \%$ in transgenics, $P<0 \cdot 05$; trabecular number was $7.9 \pm 0.3 \mathrm{~mm}^{-1}$ in controls and $5.9 \pm 0.5 \mathrm{~mm}^{-1}$ in transgenics, $P<0 \cdot 05$. In summary, $\mathrm{C} / \mathrm{EBP} \beta$ transgenics exhibited osteopenia secondary to a decrease in trabecular number without apparent changes in bone formation or bone resorption.

\section{Bone marrow stromal cell and osteoblast cultures}

To investigate the impact of C/EBP $\beta$ on osteoblastic cell function, bone marrow stromal cells from heterozygous transgenic mice and wild type littermate controls were cultured for up to 2 weeks after confluence, under conditions favoring osteoblastogenesis. $\mathrm{C} / \mathrm{EBP} \beta$ overexpression was confirmed by real-time RT-PCR, and C/EBP $\beta$ transcripts were two fold greater in transgenic than in control cells (Fig. 3A). Alkaline phosphatase mRNA levels were suppressed by about $40 \%$ in cells from transgenics, when compared with control cells (Fig. 3A). Accordingly, mineralization of the culture, tested after 14 days of incubation by alizarin red staining, was reduced in $\mathrm{C} / \mathrm{EBP} \beta$ overexpressing cells, confirming an inhibitory effect of $\mathrm{C} / \mathrm{EBP} \beta$ on osteoblastic differentiation (Fig. 3B). Conversely, osteocalcin mRNA levels were increased in $\mathrm{C} / \mathrm{EBP} \beta$ overexpressing cells (Fig. 3A). This may be explained by observations demonstrating that interactions between Runx-2 and C/EBP $\beta$ can increase osteocalcin expression (Gutierrez et al. 2002, Hata et al. 2005).

To confirm that $\mathrm{C} / \mathrm{EBP} \beta$ inhibits osteoblast differentiation, calvarial osteoblasts were harvested from heterozygous transgenic mice and wild-type littermate controls, and cultured for up to 10 days in differentiating conditions. $\mathrm{C} / \mathrm{EBP} \beta$ overexpression was confirmed by real-time RT-PCR, and C/EBP $\beta$ transcripts at confluence were 1.5-fold greater in transgenic than in control cells (Fig. 3C). Alkaline phosphatase mRNA levels were suppressed by about $50 \%$ in cells from transgenics when compared with control cells (Fig. 3C). Accordingly, calvarial osteoblasts overexpressing $\mathrm{C} / \mathrm{EBP} \beta$ exhibited decreased levels of APA when compared with control cells cultured with vehicle or BMP-2 (Fig. 3D). Osteocalcin transcript levels did not change in

Table 4 Femoral static histomorphometry of 3-month old female $\mathrm{C} / \mathrm{EBP} \beta$ heterozygous transgenic mice and wild type littermate controls

\begin{tabular}{|c|c|c|}
\hline & Wild type & $\begin{array}{l}\mathrm{C} / \mathrm{EBP} \beta \\
\text { transgenics }\end{array}$ \\
\hline $\begin{array}{l}\text { Bone volume/tissue } \\
\text { volume }(\%)\end{array}$ & $6 \cdot 9 \pm 0 \cdot 5$ & $4 \cdot 7 \pm 0 \cdot 4^{*}$ \\
\hline Trabecular separation $(\mu \mathrm{m})$ & $143 \cdot 4 \pm 6 \cdot 1$ & $213 \cdot 4 \pm 19 \cdot 1^{*}$ \\
\hline Trabecular number $\left(\mathrm{mm}^{-1}\right)$ & $6 \cdot 6 \pm 0 \cdot 3$ & $4 \cdot 6 \pm 0 \cdot 3^{*}$ \\
\hline Trabecular thickness $(\mu \mathrm{m})$ & $10 \cdot 4 \pm 0 \cdot 5$ & $10 \cdot 0 \pm 0 \cdot 3$ \\
\hline $\begin{array}{l}\text { Osteoblast surface/bone } \\
\text { surface (\%) }\end{array}$ & $13 \cdot 0 \pm 1 \cdot 3$ & $12 \cdot 1 \pm 1 \cdot 3$ \\
\hline $\begin{array}{l}\text { Number of osteoblasts/bone } \\
\text { perimeter }\left(\mathrm{mm}^{-1}\right)\end{array}$ & $22 \cdot 4 \pm 2 \cdot 0$ & $20 \cdot 5 \pm 1 \cdot 7$ \\
\hline $\begin{array}{l}\text { Number of osteoblasts/tissue } \\
\text { area }\left(\mathrm{mm}^{-2}\right)\end{array}$ & $231 \cdot 1 \pm 22 \cdot 2$ & $148 \cdot 4 \pm 15 \cdot 2^{*}$ \\
\hline $\begin{array}{l}\text { Osteoclast surface/bone } \\
\text { surface }(\%)\end{array}$ & $13 \cdot 5 \pm 1 \cdot 1$ & $12 \cdot 7 \pm 1 \cdot 5$ \\
\hline $\begin{array}{l}\text { Number of osteoclasts/bone } \\
\text { perimeter }\left(\mathrm{mm}^{-1}\right)\end{array}$ & $17 \cdot 8 \pm 1 \cdot 0$ & $17 \cdot 8 \pm 1 \cdot 6$ \\
\hline $\begin{array}{l}\text { Number of osteoclasts/tissue } \\
\text { area }\left(\mathrm{mm}^{-2}\right)\end{array}$ & $184 \cdot 4 \pm 12 \cdot 3$ & $127 \cdot 9 \pm 11 \cdot 7^{*}$ \\
\hline $\begin{array}{l}\text { Eroded surface/bone } \\
\text { surface }(\%)\end{array}$ & $33 \cdot 7 \pm 1 \cdot 6$ & $34 \cdot 1 \pm 2 \cdot 1$ \\
\hline
\end{tabular}

Bone histomorphometry was performed on femurs from 3-month old female C/EBP $\beta$ heterozygous transgenic mice and wild type littermate controls. Values are means \pm S.E.M.; $n=7-9 ; *$ Significantly different from wild type controls, $P<0.05$. 
osteoblasts from transgenics when compared with control cells (not shown), possibly because the inhibition of differentiated osteoblast function precluded the stimulatory effect of $\mathrm{C} / \mathrm{EBP} \beta$ and Runx-2 on osteocalcin transcription in mature osteoblasts.

\section{Cebpb null mice (Cebpb $\left.{ }^{-/-}\right)$}

$C e b p b^{+/-}$mice were intermated to obtain $C e b p b^{-/-}$mice, and their phenotype was examined. The homozygous Cebpb deletion causes female infertility, not allowing the establishment of a Cebpb ${ }^{-/-}$colony, and limiting the availability of mice for subsequent studies (Sterneck et al. 1997). Male Cebpb ${ }^{-1-}$ mice showed a tendency towards a reduced body weight and total body fat as compared with wild type age matched controls of identical genetic composition at 1.5 and 3 months. The difference in weight and body fat was statistically significant at 6 months of age (Fig. 4A and B). Contact radiography of male $C e b p b^{-/-}$mice did not reveal obvious skeletal abnormalities (data not shown). However, male $C e b p b^{-1-}$ mice at $1 \cdot 5,3$, and 6 months displayed a tendency toward a decrease in BMD, which was statistically significant at
1.5 months of age (Fig. 4C). Male Cebpb ${ }^{-/-}$mice at $1 \cdot 5,3$, and 6 months exhibited decreased trabecular bone volume that was statistically significant at 3 months of age (Fig. 4D).

A complete histomorphometric analysis, performed in 3-month old Cebpb ${ }^{-/-}$male mice, revealed a 30\% decrease in bone volume/tissue volume, when compared with wild type age matched controls of the same genetic composition (Table 5, Fig. 5). The decrease was secondary to a reduced number of trabeculae. Cebpb $b^{-/-}$male mice did not exhibit differences in the number of osteoblasts per bone perimeter and osteoblast surface/bone surface. Similarly, there were no significant changes in the number of osteoclasts/perimeter or in eroded surface in Cebpb null mice, when compared with wild type controls. There was no change in the number of adipocytes per tissue area possibly because $\mathrm{C} / \mathrm{EBP} \delta$ alone is sufficient to support adipogenesis (Table 5; Lane et al. 1999). No changes in mineral apposition rate (not shown) and BFR (Fig. 5) were detected. In summary, Cebpb null mice are osteopenic due to a decrease in trabecular number, but do not exhibit changes in bone formation or bone resorption.
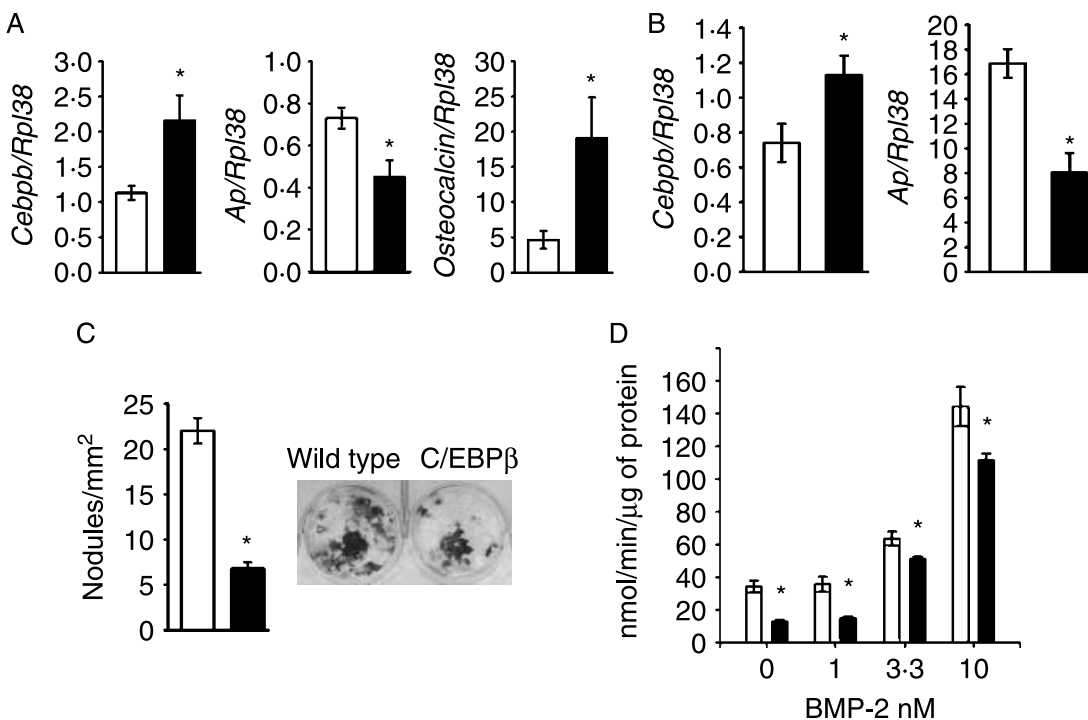

Figure 3 Effect of C/EBP $\beta$ overexpression on osteoblast differentiation in bone marrow stromal cells and calvarial osteoblasts harvested from C/EBP $\beta$ transgenic mice (black bars) and wild-type controls (white bars). In (A) stromal cells were cultured for 10 days after confluence; total RNA was reverse-transcribed, and amplified by real-time RT-PCR. Data are expressed as Cebpb, Ap, and osteocalcin copy number, corrected for Rp/38 expression. Values are means \pm s.E.M., $n=4 . *$ Significantly different from wild-type control cells, $P<0 \cdot 05$. In (B) stromal cells were cultured for 2 weeks after confluence, and mineralized nodules determined by alizarin red staining. A representative culture is shown. Values are means \pm s.E.M., $n=6$. ${ }^{*}$ Significantly different from wild-type control cells, $P<0 \cdot 05$. In (C) calvarial osteoblasts were cultured for $72 \mathrm{~h}$ after confluence; total RNA was reversetranscribed, and amplified by real-time RT-PCR. Data are expressed as Cebpb and Ap copy number corrected for $R p / 38$ expression. Values are means \pm S.E.M., $n=4 .{ }^{*}$ Significantly different from control cells, $P<0 \cdot 05$. In (D) calvarial osteoblasts were cultured to confluence, exposed to control medium or to BMP-2 at the indicated doses for $72 \mathrm{~h}$, and Ap activity was quantified in cell extracts and expressed as nanomoles of $p$-nitrophenol/min per $\mu \mathrm{g}$ of total protein. * Significantly different from control cells, $P<0 \cdot 05$. Bars represent means \pm S.E.M. for six observations. 

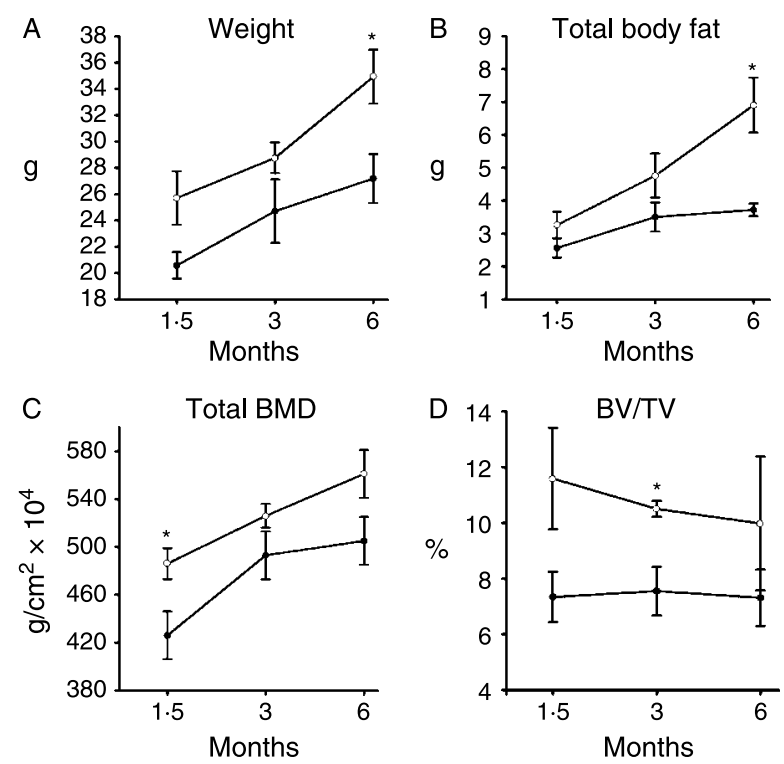

Figure 4 Weight, body composition, and bone volume/tissue volume (BV/TV) in male Cebpb null mice (filled circles) and wildtype age matched controls (open circles). The weight (A), total body fat (B), total BMD (BMD, C), and BV/TV (D) of male Cebpb null mice and wild type age matched controls of the same genetic composition at $1 \cdot 5,3$, and 6 months of age is shown. *Significantly different from control mice, $P<0 \cdot 05$. Bars represent means \pm s.E.M., $n=5$.

\section{Downregulation of $C / E B P \beta$}

Skeletal cells from Cebp ${ }^{-/-}$mice were not readily available because of the low fertility of Cebph ${ }^{+/-}$mice and infertility of $C e b p b^{-/-}$mice. To investigate the function of $\mathrm{C} / \mathrm{EBP} \beta$, its mRNA levels were downregulated by RNA interference (RNAi) in primary calvarial osteoblasts. C/EBP $\beta$ downregulation was confirmed by real-time RT-PCR, and $\mathrm{C} / \mathrm{EBP} \beta$ transcripts were reduced by $70 \%$ in cells transfected with the C/EBP $\beta$ siRNA, when compared with control cells transfected with scrambled siRNA (Table 6). There were no changes in alkaline phosphatase or osteocalcin mRNA levels, measured by real-time RT-PCR, in C/EBP $\beta$ downregulated cells (Table 6). Accordingly, there was no effect on APA in cells transfected with C/EBP $\beta$ siRNA when compared with control cells (Table 6). These results indicate that C/EBP $\beta$ may be dispensable for osteoblast differentiation in vitro, and suggest that the osteopenic phenotype of the null mutation could be secondary to indirect mechanisms.

\section{Discussion}

This report demonstrates that transgenic mice overexpressing $\mathrm{C} / \mathrm{EBP} \beta$ under the control of the $3.8 \mathrm{~kb}$ human osteocalcin promoter exhibit osteopenia. The osteopenia was secondary to a reduced number of trabeculae, but $\mathrm{C} / \mathrm{EBP} \beta$ transgenics exhibited no change in osteoblast number or BFR.

The osteopenic phenotype could not be attributed to changes in bone resorption, since, osteoclast number, eroded surface, and biochemical markers of bone remodeling were not different between transgenics and controls. The reduced number of trabeculae could be the result of impaired trabecular formation during skeletal development. This is possible since the osteocalcin promoter is expressed by mature osteoblasts as early as day 18 of embryonic life (Frendo et al. 1998, Kalajzic et al. 2002), and C/EBP $\beta$ overexpression can suppress the terminal differentiation of osteoblasts (Iyer $e$ t al. 2004). A possible explanation for a developmental impact of $\mathrm{C} / \mathrm{EBP} \beta$ could be a suppression of Runx-2 transcription, and as a consequence, impaired trabecular bone formation (Otto et al. 1997, Wiper-Bergeron et al. 2007). It is possible that osteoblastic differentiation and function are more sensitive to transcriptional changes during development, or that compensatory mechanisms are established postnatally, since osteoblast number and bone formation were not affected in 1-month old C/EBP $\beta$ transgenics.

Cebpb null mice showed reduced weight, total body fat, and total BMD. Although they were osteopenic, no changes in osteoblast or osteoclast number or BFR were observed. The osteopenic phenotype of Cebpb null mice is in accordance with recent reports from other investigators (Staiger et al. 2008, Tominaga et al. 2008), and with a function of C/EBP $\beta$ in the early differentiation stages of mesenchymal cells, resulting in impaired chondrocyte and osteoblast maturation. This leads to impaired cartilage and bone development, and would explain the reduced number of trabeculae and

Table 5 Femoral static histomorphometry of 3-month old male Cebpb null mice and male wild-type age matched controls

Bone volume/tissue volume (\%)

Trabecular separation $(\mu \mathrm{m})$

Trabecular number $\left(\mathrm{mm}^{-1}\right)$

Trabecular thickness $(\mu \mathrm{m})$

Osteoblast surface/bone surface $(\%)$

Number of osteoblasts/bone perimeter $\left(\mathrm{mm}^{-1}\right)$

Number of osteoblasts/tissue area $\left(\mathrm{mm}^{-2}\right)$

Osteoclast surface/bone surface $(\%)$

Number of osteoclasts/bone perimeter $\left(\mathrm{mm}^{-1}\right)$

Number of osteoclasts/tissue area $\left(\mathrm{mm}^{-2}\right)$

Eroded surface/bone surface $(\%)$

Number of adipocytes/tissue area $\left(\mathrm{mm}^{-2}\right)$

\begin{tabular}{ccc} 
Wild type & & Cebph $^{-1-}$ \\
$10 \cdot 5 \pm 0 \cdot 3$ & & $7 \cdot 5 \pm 0 \cdot 9^{*}$ \\
$114 \cdot 1 \pm 4 \cdot 0$ & & $149 \cdot 3 \pm 11 \cdot 9^{*}$ \\
$7 \cdot 9 \pm 0 \cdot 3$ & & $6 \cdot 3 \pm 0 \cdot 5^{*}$ \\
$13 \cdot 3 \pm 0 \cdot 4$ & & $12 \cdot 1 \pm 0 \cdot 7$ \\
$11 \cdot 6 \pm 1 \cdot 8$ & & $10 \cdot 6 \pm 1 \cdot 2$ \\
$18 \cdot 0 \pm 2 \cdot 5$ & & $17 \cdot 7 \pm 2 \cdot 1$ \\
$226 \cdot 4 \pm 36 \cdot 3$ & & $175 \cdot 1 \pm 23 \cdot 0$ \\
$4 \cdot 1 \pm 0 \cdot 8$ & & $5 \cdot 7 \pm 1 \cdot 0$ \\
$3 \cdot 5 \pm 0 \cdot 7$ & $5 \cdot 2 \pm 0 \cdot 9$ \\
$43 \cdot 3 \pm 9 \cdot 0$ & $51 \cdot 0 \pm 9 \cdot 2$ \\
$14 \cdot 6 \pm 1 \cdot 7$ & $17 \cdot 2 \pm 1 \cdot 2$ \\
$35 \cdot 9 \pm 11 \cdot 7$ & $15 \cdot 3 \pm 5 \cdot 2$ \\
\hline
\end{tabular}

Bone histomorphometry was performed on femurs from 3-month old male $\mathrm{Cebph}^{-1-}$ mice and male wild type age matched controls of the same genetic composition. Values are means \pm S.E.M.; $n=5$; * Significantly different from wild type controls, $P<0 \cdot 05$. 

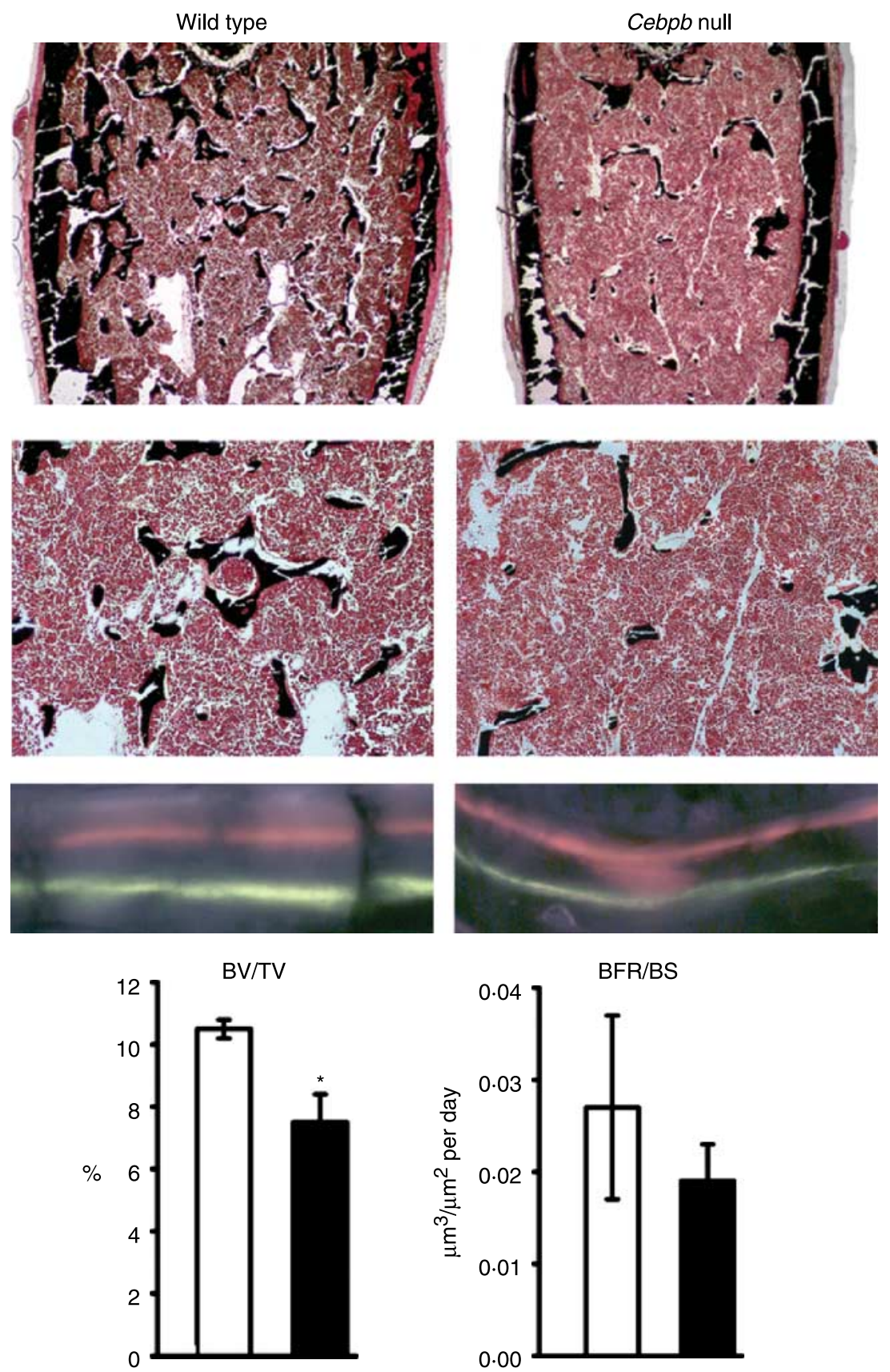

Figure 5 Representative histological sections and calcein/demeclocycline labels (upper panels) of bone femoral sections from 3-month old Cebpb null mice and wild-type littermate controls stained with von Kossa without counter stain (final magnification $40 \times$ and $100 \times$ ) or unstained and examined under fluorescence microscopy (final magnification $100 \times$ ). In the lower panels, bars represent bone volume/tissue volume (BV/TV, \%), and BFR/bone surface (BFR/BS, $\mu \mathrm{m}^{3} / \mu \mathrm{m}^{2}$ per day) of Cebpb null (black bars) and wild-type controls (white bars). Values are means \pm S.E.M., $n=5$. * Significantly different from control mice, $P<0 \cdot 05$.

osteopenic phenotype (Tominaga et al. 2008). However, other factors probably contribute to the bone loss caused by the $C e b p b$ deletion, since $\mathrm{C} / \mathrm{EBP} \beta$ regulates gene expression in a variety of organs (Ramji \& Foka 2002). Cebpb null mice have decreased serum levels of insulin like growth factor I (IGF-I), secondary to decreased IGF-I expression by the liver (Staiger et al. 2008), and systemic IGF-I plays an important role in skeletal homeostasis (Gazzerro \& Canalis 2006, Yakar et al. 
Table 6 Effect of C/EBP downregulation by RNAi on osteoblastic markers in calvarial osteoblasts

\begin{tabular}{llll} 
& siScrambled & & siC/EBP $\boldsymbol{\beta}$ \\
\cline { 2 - 2 } Cebpb/Rp/38 & $9 \cdot 15 \pm 1 \cdot 37$ & & $2 \cdot 41 \pm 1 \cdot 12 *$ \\
Alkaline phosphatase/Rpl38 & $1 \cdot 78 \pm 0 \cdot 22$ & & $2 \cdot 09 \pm 0 \cdot 71$ \\
Osteocalcin/Rpl38 & $3 \cdot 05 \pm 1 \cdot 25$ & & $2 \cdot 28 \pm 0 \cdot 70$ \\
APA & $6 \cdot 87 \pm 0 \cdot 84$ & & $5 \cdot 87 \pm 0 \cdot 82$
\end{tabular}

Cebpb, alkaline phosphatase and osteocalcin copy number, corrected for Rpl38 expression, were determined by real-time RT-PCR in calvarial osteoblasts transfected with siC/EBP $\beta$ or siScrambled control. APA $(\mathrm{nmol} / \mathrm{min}$ per $\mu \mathrm{g}$ of protein) was determined in parallel cultures. Values are means \pm S.E.M., $n=4-6 .{ }^{*}$ Significantly different from control cells, $P<0 \cdot 05$.

2006, Giustina et al. 2008). Other contributing factors to the osteopenic phenotype could be the consequences of lymphoproliferative and myeloproliferative alterations, and increased Interleukin-6 serum levels exhibited in the Cebpb null state (Screpanti et al. 1995). Uncontrolled proliferation of lymphocytes or myeloid precursors can lead to osteopenia (Roodman 1997), and overexpression of Interleukin-6 in vivo causes impaired growth plate development, increased bone resorption, and decreased osteoblastic differentiation (De et al. 2006). A systemic nature of the osteopenic phenotype, as opposed to an osteoblast specific effect, is supported by the absence of a cellular phenotype following the downregulation of $\mathrm{C} / \mathrm{EBP} \beta$ by RNAi in osteoblasts. However, the absence of a cellular phenotype is in contrast with recently reported findings in osteoblasts from Cebpb null mutants, where inactivation of Cebpb resulted in impaired osteoblast maturation (Tominaga et al. 2008). The discrepancy between our results and those of Tominaga et al., could be attributed to the transient and possibly incomplete downregulation of $\mathrm{C} / \mathrm{EBP} \beta$ by RNAi, causing sufficient $\mathrm{C} / \mathrm{EBP} \beta$ expression to support osteoblast differentiation/function for the period of study. It is also possible that under the experimental conditions used in the present work, the levels of C/EBP $\beta$ were sufficient to maintain osteocalcin expression (Gutierrez et al. 2002). C/EBP $\beta$ can favor the early stages of osteoblast differentiation through its hetero-dimerization with activating transcription factor (ATF) 4, and by enhancing the association of ATF 4 with Runx-2 to regulate osteocalcin transcription (Hata et al. 2005, Tominaga et al. 2008). Interactions of $\mathrm{C} / \mathrm{EBP} \beta$ with ATF 4 may affect other steps of osteoblastic differentiation, since ATF 4 plays an essential role in this process (Yang et al. 2004), and could also explain the findings reported in Cebpb null osteoblasts and in the Cebpb null mice.

Evidence for direct activity of $\mathrm{C} / \mathrm{EBP} \beta$ in osteoblasts also can be derived from observations in vivo. Transgenics overexpressing either LIP, a physiological dominant negative form of $\mathrm{C} / \mathrm{EBP} \beta$ (Harrison et al. 2005), or CHOP, a member of the C/EBP family, are osteopenic (Pereira et al. 2007). The primary partner of $\mathrm{CHOP}$ is $\mathrm{C} / \mathrm{EBP} \beta$ and the osteopenia observed in CHOP transgenics is likely secondary to its dimerization with $\mathrm{C} / \mathrm{EBP} \beta$ and a decrease in $\mathrm{C} / \mathrm{EBP} \beta$ transactivating activity in the skeletal environment (Ron \& Habener 1992, Vinson et al. 2002). It is of interest that inactivation of Chop causes decreased bone formation, but not an obvious osteopenic phenotype. The function of CHOP, like that of $\mathrm{C} / \mathrm{EBP} \beta$, appears to be dependent on cell type, stage of mesenchymal/osteoblastic cell differentiation, and experimental conditions (Pereira \& Delany 2004, Pereira et al. 2006, Shirakawa et al. 2006).

To understand the mechanism leading to the osteopenic phenotype resulting from $\mathrm{C} / \mathrm{EBP} \beta$ overexpression, we examined primary osteoblasts and bone marrow stromal cells harvested from $\mathrm{C} / \mathrm{EBP} \beta$ transgenic mice. The cellular phenotype is in accordance with the osteopenic phenotype observed, and with previous work demonstrating that the stable transduction of C/EBP $\beta$ in MC3T3 and C3H10T1/2 cells, by repressing Runx-2 transcription, abrogates osteoblast differentiation induced by retinoic acid (Wiper-Bergeron et al. 2007). Accordingly, osteoblastic cells from C/EBP $\beta$ transgenics exhibited reduced mineralization, APA, and alkaline phosphatase mRNA expression. By contrast, transduction of cells of the osteoblastic lineage with adenoviral vectors expressing $\mathrm{C} / \mathrm{EBP} \beta$ resulted in enhanced osteoblastic differentiation (Hata et al. 2005), also suggesting that experimental conditions can have a significant impact on the effect of C/EBPs in osteoblasts. C/EBP $\beta / A T F ~ 4 / R u n x-2$ interactions enhance osteocalcin transcription, and osteocalcin transcripts are increased in conditions of $\mathrm{C} / \mathrm{EBP} \beta$ overexpression (Gutierrez et al. 2002, Tominaga et al. 2008). Accordingly, osteocalcin mRNA levels were increased in bone marrow stromal cell cultures from $\mathrm{C} / \mathrm{EBP} \beta$ transgenics. However, they were not changed in calvarial osteoblasts, possibly due to the inhibitory effect of C/EBP $\beta$ on Runx-2 expression and on terminal osteoblast differentiation (Iyer et al. 2004, Wiper-Bergeron et al. 2007).

$\mathrm{C} / \mathrm{EBP} \beta$ is involved in cell-fate decisions and regulates the balance between osteoblasts and adipocytes in vitro, and the Cebpb deletion in vivo impairs the formation of white and brown adipose tissue (Tanaka et al. 1997, Hata et al. 2005). Accordingly, male Cebpb null mice exhibited reduced total body fat. The Cebpb deletion did not affect the number of bone marrow adipocytes, possibly because $\mathrm{C} / \mathrm{EBP} \delta$ is sufficient to sustain adipogenesis in the absence of C/EBP $\beta$ (Lane et al. 1999). However, the effect of the Cebpb deletion on the differentiation of bone marrow adipocytes in vivo is not known, and it is conceivable that genes regulating the development of brown and white adipose tissue could be different from genes regulating bone marrow adipogenesis. We did not detect an effect on total body fat or in the number of adipocytes in $\mathrm{C} / \mathrm{EBP} \beta$ transgenics. This should be expected, since $\mathrm{C} / \mathrm{EBP} \beta$ was expressed under the control of the osteocalcin promoter, which is expressed by mature osteoblasts and not by undifferentiated mesenchymal cells capable of adipocytic differentiation.

In conclusion, $\mathrm{C} / \mathrm{EBP} \beta$ plays an important regulatory role in osteoblast differentiation and skeletal function in vivo. 


\section{Declaration of interest}

The authors declare that there is no conflict of interest that could be perceived as prejudicing the impartiality of the research reported.

\section{Funding}

This work was supported by Grant DK042424 from the National Institute of Diabetes and Digestive and Kidney Diseases.

\section{Acknowledgements}

The authors thank S Akira for Cebpb heterozygous null mice, S L McKnight for C/EBP $\beta$ cDNA, J B Lian for osteocalcin cDNA, E Gardiner for human osteocalcin promoter construct, Melissa Burton, Trung X Le and Kristen McBreairty for technical assistance, and Mary Yurczak for secretarial assistance.

\section{References}

Bianco P \& Gehron RP 2000 Marrow stromal stem cells. Journal of Clinical Invesigation 105 1663-1668.

Calkhoven CF, Muller C \& Leutz A 2000 Translational control of $\mathrm{C} / \mathrm{EBP}$ alpha and C/EBPbeta isoform expression. Genes Development 14 1920-1932.

Canalis E, Deregowski V, Pereira RC \& Gazzerro E 2005 Signals that determine the fate of osteoblastic cells. Journal of Endocrinological Investigation 28 3-7.

Cao Z, Umek RM \& McKnight SL 1991 Regulated expression of three $\mathrm{C} / \mathrm{EBP}$ isoforms during adipose conversion of 3T3-L1 cells. Genes Development 5 1538-1552.

Cesena TI, Cardinaux JR, Kwok R \& Schwartz J 2007 CCAAT/enhancerbinding protein $(\mathrm{C} / \mathrm{EBP})$ beta is acetylated at multiple lysines: acetylation of $\mathrm{C} / \mathrm{EBPbeta}$ at lysine 39 modulates its ability to activate transcription. Journal of Biological Chemistry 282 956-967.

Clarke SL, Robinson CE \& Gimble JM 1997 CAAT/enhancer binding proteins directly modulate transcription from the peroxisome proliferatoractivated receptor gamma 2 promoter. Biochemical and Biophysical Research Communications 240 99-103.

Croniger CM, Millward C, Yang J, Kawai Y, Arinze IJ, Liu S, Harada-Shiba M, Chakravarty K, Friedman JE, Poli V et al. 2001 Mice with a deletion in the gene for CCAAT/enhancer-binding protein beta have an attenuated response to cAMP and impaired carbohydrate metabolism. Journal of Biological Chemistry 276 629-638.

Dahl LK 1952 A simple and sensitive histochemical method for calcium. Proceedings of the Society for Experimental Biology and Medicine 80 474-479.

De BF, Rucci N, Del FA, Peruzzi B, Paro R, Longo M, Vivarelli M, Muratori F, Berni S, Ballanti P et al. 2006 Impaired skeletal development in interleukin-6-transgenic mice: a model for the impact of chronic inflammation on the growing skeletal system. Arthritis and Rheumatism $\mathbf{5 4}$ 3551-3563.

Elbashir SM, Harborth J, Lendeckel W, Yalcin A, Weber K \& Tuschl T 2001 Duplexes of 21-nucleotide RNAs mediate RNA interference in cultured mammalian cells. Nature 411 494-498.

Franceschi RT, Ge C, Xiao G, Roca H \& Jiang D 2007 Transcriptional regulation of osteoblasts. Annals of the New York Academy of Sciences 1116 196-207.

Frendo JL, Xiao G, Fuchs S, Franceschi RT, Karsenty G \& Ducy P 1998 Functional hierarchy between two OSE2 elements in the control of osteocalcin gene expression in vivo. Journal of Biological Chemistry 273 30509-30516.
Frenkel B, Capparelli C, Van Auken M, Baran D, Bryan J, Stein JL, Stein GS \& Lian JB 1997 Activity of the osteocalcin promoter in skeletal sites of transgenic mice and during osteoblast differentiation in bone marrow-derived stromal cell cultures: effects of age and sex. Endocrinology 138 2109-2116.

Gazzerro E \& Canalis E 2006 Skeletal actions of insulin-like growth factors. Expert Review of Endocrinology and Metabolism 1 47-56.

Gazzerro E, Pereira RC, Jorgetti V, Olson S, Economides AN \& Canalis E 2005 Skeletal overexpression of gremlin impairs bone formation and causes osteopenia. Endocrinology 146 655-665.

Giustina A, Mazziotti G \& Canalis E 2008 Growth hormone, insulin-like growth factors, and the skeleton. Endocrine Reviews 29 535-559.

Greenbaum LE, Li W, Cressman DE, Peng Y, Ciliberto G, Poli V \& Taub RC 1998 CCAAT enhancer- binding protein beta is required for normal hepatocyte proliferation in mice after partial hepatectomy. Journal of Clinical Invesigation 102 996-1007.

Gutierrez S, Javed A, Tennant DK, van Rees M, Montecino M, Stein GS, Stein JL \& Lian JB 2002 CCAAT/enhancer-binding proteins (C/EBP) beta and delta activate osteocalcin gene transcription and synergize with Runx2 at the $\mathrm{C} / \mathrm{EBP}$ element to regulate bone-specific expression. Journal of Biological Chemistry 277 1316-1323.

Harrison JR, Huang YF, Wilson KA, Kelly PL, Adams DJ, Gronowicz GA \& Clark SH 2005 Col1a1 promoter-targeted expression of p20 CCAAT enhancer-binding protein beta (C/EBPbeta), a truncated C/EBPbeta isoform, causes osteopenia in transgenic mice. Journal of Biological Chemistry $2808117-8124$

Hata K, Nishimura R, Ueda M, Ikeda F, Matsubara T, Ichida F, Hisada K, Nokubi T, Yamaguchi A \& Yoneda T 2005 A CCAAT/enhancer binding protein beta isoform, liver-enriched inhibitory protein, regulates commitment of osteoblasts and adipocytes. Molecular Cell Biology 25 1971-1979.

Irwin N 1989 Molecular coning. In Sambrook, pp 9·32-9·36. Ed. J FEMT. New York: Cold Spring Harbor Laboratory Press.

Iyer VV, Kadakia TB, McCabe LR \& Schwartz RC 2004 CCAAT/enhancerbinding protein-beta has a role in osteoblast proliferation and differentiation. Experimental Cell Research 295 128-137.

Kalajzic Z, Liu P, Kalajzic I, Du Z, Braut A, Mina M, Canalis E \& Rowe DW 2002 Directing the expression of a green fluorescent protein transgene in differentiated osteoblasts: comparison between rat type I collagen and rat osteocalcin promoters. Bone 31 654-660.

Kouadjo KE, Nishida Y, Cadrin-Girard JF, Yoshioka M \& St-Amand J 2007 Housekeeping and tissue-specific genes in mouse tissues. BMC Genomics 8127.

Lane MD, Tang QQ \& Jiang MS 1999 Role of the CCAAT enhancer binding proteins (C/EBPs) in adipocyte differentiation. Biochemical and Biophysical Research Communications 266 677-683.

Li X, Kim JW, Gronborg M, Urlaub H, Lane MD \& Tang QQ 2007 Role of cdk2 in the sequential phosphorylation/activation of $\mathrm{C} / \mathrm{EBPbeta}$ during adipocyte differentiation. PNAS 104 11597-11602.

Lian J, Stewart C, Puchacz E, Mackowiak S, Shalhoub V, Collart D, Zambetti G \& Stein G 1989 Structure of the rat osteocalcin gene and regulation of vitamin D-dependent expression. PNAS 86 1143-1147.

McCarthy TL, Centrella M \& Canalis E 1990 Cortisol inhibits the synthesis of insulin-like growth factor-I in skeletal cells. Endocrinology 126 1569-1575.

Nagy TR, Prince CW \& Li J 2001 Validation of peripheral dual-energy X-ray absorptiometry for the measurement of bone mineral in intact and excised long bones of rats. Journal of Bone and Mineral Research 16 1682-1687.

Nazarenko I, Lowe B, Darfler M, Ikonomi P, Schuster D \& Rashtchian A 2002a Multiplex quantitative PCR using self-quenched primers labeled with a single fluorophore. Nucleic Acids Research 30 e37.

Nazarenko I, Pires R, Lowe B, Obaidy M \& Rashtchian A $2002 b$ Effect of primary and secondary structure of oligodeoxyribonucleotides on the fluorescent properties of conjugated dyes. Nucleic Acids Research 30 2089-2195.

Nerlov C 2007 The C/EBP family of transcription factors: a paradigm for interaction between gene expression and proliferation control. Trends in Cell Biology 17 318-324.

Otto F, Thornell AP, Crompton T, Denzel A, Gilmour KC, Rosewell IR, Stamp GW, Beddington RS, Mundlos S, Olsen BR et al. 1997 Cbfa1, a candidate gene for cleidocranial dysplasia syndrome, is essential for osteoblast differentiation and bone development. Cell 89 765-771. 
Parfitt AM, Drezner MK, Glorieux FH, Kanis JA, Malluche H, Meunier PJ, Ott SM \& Recker RR 1987 Bone histomorphometry: standardization of nomenclature, symbols, and units. Reprt of the ASBMR histomorphometry nomenclature committee. Journal of Bone and Mineral Research 2 595-610.

Pereira RC, Delany AM \& Canalis E 2002 Effects of cortisol and BMP-2 on stromal cell differentiation: correlation with CCAAT-enhancer binding protein expression. Bone 30 685-691.

Pereira RC, Delany AM \& Canalis E 2004 CCAAT/enhancer binding protein homologous protein (DDIT3) induces osteoblastic cell differentiation. Endocrinology 145 1952-1960.

Pereira RC, Stadmeyer L, Marciniak SJ, Ron D \& Canalis E 2006 C/EBP homologous protein is necessary for normal osteoblastic function. Journal of Cellular Biochemistry 97 633-640.

Pereira RC, Stadmeyer L, Smith DL, Rydziel S \& Canalis E 2007 CCAAT/enhancer binding protein homologous protein (CHOP) decreases bone formation and causes osteopenia. Bone 40 619-626.

Ramji DP \& Foka P 2002 CCAAT/enhancer-binding proteins: structure, function and regulation. Biochemistry Journal 365 561-575.

Ron D \& Habener JF 1992 CHOP, a novel developmentally regulated nuclear protein that dimerizes with transcription factors C/EBP and LAP and functions as a dominant-negative inhibitor of gene transcription. Genes Development 6 439-453.

Roodman GD 1997 Mechanisms of bone lesions in multiple myeloma and lymphoma. Cancer 80 1557-1563.

Rosen ED, Walkey CJ, Puigserver P \& Spiegelman BM 2000 Transcriptional regulation of adipogenesis. Genes Development 14 1293-1307.

Screpanti I, Romani L, Musiani P, Modesti A, Fattori E, Lazzaro D, Sellitto C, Scarpa S, Bellavia D \& Lattanzio G 1995 Lymphoproliferative disorder and imbalanced T-helper response in C/EBP beta-deficient mice. EMBO Journal 14 1932-1941.

Sharp PA 2001 RNA interference-2001. Genes Development 15 485-490.

Shirakawa K, Maeda S, Gotoh T, Hayashi M, Shinomiya K, Ehata S, Nishimura R, Mori M, Onozaki K, Hayashi H et al. 2006 CCAAT/ enhancer-binding protein homologous protein (CHOP) regulates osteoblast differentiation. Molecular Cell Biology 26 6105-6116.

Sims NA, White CP, Sunn KL, Thomas GP, Drummond ML, Morrison NA, Eisman JA \& Gardiner EM 1997 Human and murine osteocalcin gene expression: conserved tissue restricted expression and divergent responses to 1,25-dihydroxyvitamin D3 in vivo. Molecular Endocrinology 11 1695-1708.

Staiger J, Lueben MJ, Berrigan D, Malik R, Perkins SN, Hursting SD \& Johnson PF 2008 C/EBP $\beta$ regulates body composition, energy balancerelated hormones, and tumor growth. Carcinogenesis (in press) DOI: 10.1093/CARCIN/BGN273.

Sterneck E, Tessarollo L \& Johnson PF 1997 An essential role for C/EBPbeta in female reproduction. Genes Development 11 2153-2162.
Tanaka T, Akira S, Yoshida K, Umemoto M, Yoneda Y, Shirafuji N, Fujiwara H, Suematsu S, Yoshida N \& Kishimoto T 1995 Targeted disruption of the NF-IL6 gene discloses its essential role in bacteria killing and tumor cytotoxicity by macrophages. Cell 80 353-361.

Tanaka T, Yoshida N, Kishimoto T \& Akira S 1997 Defective adipocyte differentiation in mice lacking the C/EBPbeta and/or C/EBPdelta gene. EMBO Journal 16 7432-7443.

Tang QQ, Gronborg M, Huang H, Kim JW, Otto TC, Pandey A \& Lane MD 2005 Sequential phosphorylation of CCAAT enhancer-binding protein beta by MAPK and glycogen synthase kinase 3 beta is required for adipogenesis. PNAS 102 9766-9771.

Tominaga H, Maeda S, Hayashi M, Takeda S, Akira S, Komiya S, Nakamura T, Akiyama H \& Imamura T 2008 CCAAT/enhancer-binding protein beta promotes osteoblast differentiation by enhancing Runx2 activity with ATF4. Molecular Biology of the Cell 19 5373-5386.

Vinson C, Myakishev M, Acharya A, Mir AA, Moll JR \& Bonovich M 2002 Classification of human B-ZIP proteins based on dimerization properties. Molecular Cell Biology 22 6321-6335.

Winslow MM, Pan M, Starbuck M, Gallo EM, Deng L, Karsenty G \& Crabtree GR 2006 Calcineurin/NFAT signaling in osteoblasts regulates bone mass. Developmental Cell 10 771-782.

Wiper-Bergeron N, St-Louis C \& Lee JM 2007 CCAAT/enhancer binding protein beta abrogates retinoic acid-induced osteoblast differentiation via repression of Runx2 transcription. Molecular Endocrinology 21 2124-2135.

Yakar S, Bouxsein ML, Canalis E, Sun H, Glatt V, Gundberg C, Cohen P, Hwang D, Boisclair Y, LeRoith D et al. 2006 The ternary IGF complex influences postnatal bone acquisition and the skeletal response to intermittent parathyroid hormone. Journal of Endocrinology 189 289-299.

Yang TT \& Chow CW 2003 Transcription cooperation by NFAT.C/EBP composite enhancer complex. Journal of Biological Chemistry 278 1587415885 .

Yang X, Matsuda K, Bialek P, Jacquot S, Masuoka HC, Schinke T, Li L, Brancorsini S, Sassone-Corsi P, Townes TM et al. 2004 ATF4 is a substrate of RSK2 and an essential regulator of osteoblast biology; implication for Coffin-Lowry syndrome. Cell 117 387-398.

Received in final form 23 January 2009

Accepted 11 February 2009

Made available online as an Accepted Preprint 11 February 2009 